\title{
ANALISIS PROSEDUR PENERIMAAN PASIEN RAWAT JALAN GUNA MENUNJANG EFEKTIVITAS PELAYANAN DI RUMAH SAKIT X
}

\author{
Risa Fitria Ripriyanti ${ }^{1 *}$, Meira Hidayati ${ }^{2}$ \\ Politeknik Piksi Ganesha, Indonesia ${ }^{1,2}$ \\ fitriarisa91@ gmail.com*, meira.hidayati@piksi.ac.id ${ }^{2}$
}

Received: 31-08-2021

Revised : 18-10-2021

Accepted: $20-10-2021$

\begin{abstract}
Abstrak
Latar Belakang: Salah satu kegiatan rekam medis di Rumah Sakit X yang pertama adalah penerimaan pasien di rawat jalan atau rawat inap. Prosedur penerimaan pasien rawat jalan sangat penting terhadap proses pelayanan kesehatan di rumah sakit.
\end{abstract}

Tujuan: Penelitian ini dilakukan dengan tujuan untuk mengetahui prosedur penerimaan Pasien Rawat Jalan guna Menunjang Efektivitas Pelayanan Rekam Medis di Rumah Sakit X.

Metode: Metode yang digunakan penulis adalah metode penelitian yang bersifat kualitatif dengan rancangan penelitian yang digunakan adalah studi kasus.

Hasil: Dari penelitian yang dilakukan ada beberapa masalah diantaranya: (1) ketidaklengkapan informasi dari pihak pasien atau pengantar pasien / keluarga pasien kepada petugas untuk diinputkan data nya pada sistem pendaftaran, (2) Error nya sistem pendaftaran karena koneksi jaringan internet yang kurang baik pada saat petugas akan menginput data pasien.

Kesimpulan: Upaya pemecahan masalah yang telah dilakukan oleh petugas pendaftaran diantaranya mensosialisasikan kelengkapan data pasien seperti KTP atau kartu pengenal lainnya, dan petugas pendaftaran berupaya untuk menginput data pasien kembali dengan cepat pada saat jaringan koneksi internet sudah membaik.

Kata kunci: prosedur penerimaan pasien rawat jalan, efektivitas pelayanan.

\footnotetext{
Abstract

Background: One of the first medical record activities at Hospital $X$ is the admission of patients in outpatient or inpatient settings. The procedure for accepting outpatients is very important in the process of health services in hospitals.

Objective: This study was conducted with the aim of knowing the procedure for accepting Outpatients to Support the Effectiveness of Medical Record Services at Hospital X.
} 


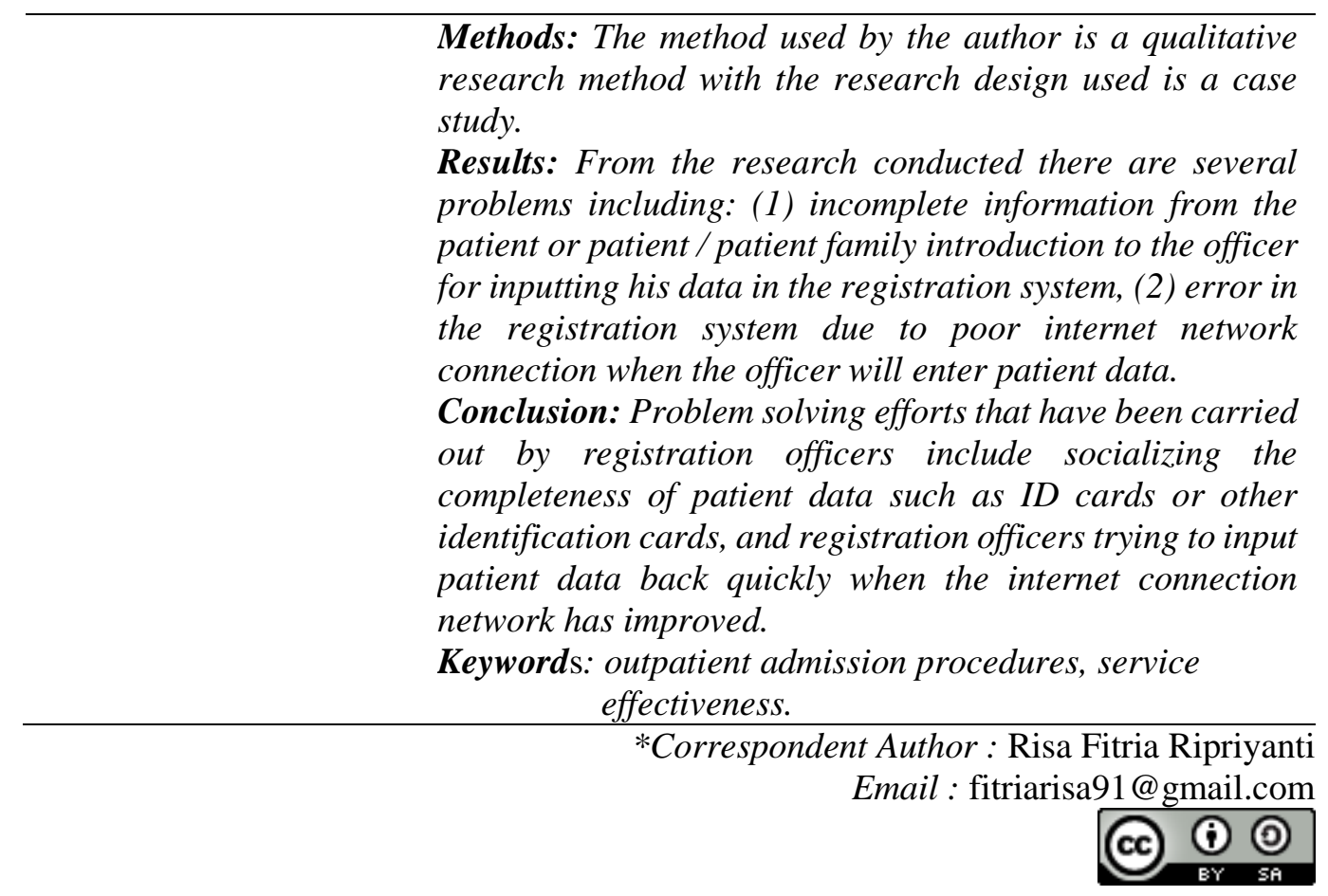

\section{PENDAHULUAN}

Menurut Undang - Undang Republik Indonesia Nomor 44 Tahun 2009 Pasal 1 Tentang Rumah Sakit, menyatakan bahwa "Rumah Sakit adalah institusi pelayanan kesehatan yang menyelenggarakan pelayanan kesehatan perorangan secara paripurna yang menyediakan pelayanan rawat inap, rawat jalan, dan gawat darurat" (Indonesia, 44 C.E.). Rumah sakit merupakan sarana pelayanan kesehatan yang di dalamnya mencakup pelayanan rawat jalan, rawat inap, dan instalasi gawat darurat (IGD).

Rumah sakit sebagai salah satu pelayanan kesehatan yang melakukan rawat jalan maupun rawat inap (Supartiningsih, 2017). Pasien datang ke rumah sakit pertama kali mendapatkan pelayanan di bagian penerimaan pasien (pendaftaran) terlebih dahulu, pendaftaran sebagai pelayanan pertama tentu saja menentukan seberapa baik kualitas pelayanan di rumah sakit. Oleh sebab itu, suatu pelayanan dibutuhkan suatu prosedur penerimaan pasien agar pasien memiliki kepuasan dalam pelayanan di suatu rumah sakit.

Setelah datang ke pendaftaran tentu saja pasien akan memiliki rekam medis, pengisian data rekam medis bertujuan untuk mendokumentasikan semua data pasien mulai dari pasien masuk rumah sakit sampai dengan pasien keluar dari rumah sakit. Menurut PerMenKes No.269/MENKES/PER/III/2008 menyatakan bahwa "Rekam Medis adalah berkas yang berisikan catatan dokumen tentang identitas pasien, pemeriksaan, pengobatan, tindakan dan pelayanan lain yang telah diberikan kepada pasien" (Permenkes, 2008). Rekam medis sangat penting untuk meningkatkan mutu pelayanan, baik rawat jalan maupun rawat inap di suatu rumah sakit.

Menurut Sedarmayanti mengungkapkan bahwa "Efektivitas pelayanan adalah suatu tindakan atau kegiatan yang diberikan dengan harapan dapat memiliki nilai guna bagi si pemakai jasa pelayanan, dalam artian pelayanan yang diberikan tidak sia-sia atau bermanfaat dan menghasilkan pelayanan yang cepat dan tepat sehingga dapat tercapai tujuan yang dimaksud (Sedarmayanti, 2009)

Kegiatan yang dilakukan di unit rekam medis sangat beragam, mulai dari penerimaan pasien hingga pengelolaan rekam medis, unit rekam medis juga merupakan unit penyedia informasi yang mana informasi tersebut dapat digunakan sebagai bukti 
tertulis mengenai proses pelayanan yang diberikan kepada pasien, dan sebagai acuan dalam perencanaan terapi atau pengobatan berikutnya (Sitanggang, 2019).

Salah satu kegiatan rekam medis di Rumah Sakit X yang pertama adalah penerimaan pasien di rawat jalan atau rawat inap. Penerimaan pasien rawat jalan di Rumah Sakit X cukup baik dan sesuai dengan Direktorat Jenderal Bina Pelayanan Medik tentang sistem informasi manajemen Rumah Sakit yang terintegrasi komputerisasi. Namun ada sedikit keterlambatan saat penerimaan pasien diantaranya saat pasien kurang membawa persyaratan untuk berobat dan masih ada terjadinya error pada sistem informasi di bagian pendaftaran.

Berdasarkan hasil penelitian yang dilakukan menunjukan bahwa dalam prosedur penerimaan pasien rawat jalan masih ada kekurangan, diantaranya ketidaklengkapan informasi data dari pihak pengantar pasien atau keluarga pasien kepada petugas untuk di input datanya, kekeliruan petugas karena sistem informasi di pendaftaran pada saat akan mendaftarkan pasien error. Oleh karena itu prosedur penerimaan pasien rawat jalan perlu perhatian yang serius dari rumah sakit sehingga sistem informasi manajemen rumah sakit dapat berjalan sebagaimana yang diharapkan.

Penelitian ini bertujuan untuk mengetahui prosedur penerimaan Pasien Rawat Jalan guna Menunjang Efektivitas Pelayanan Rekam Medis di Rumah Sakit X.

\section{METODE PENELITIAN}

Menurut Sugiyono, metodologi Penelitian pada dasarnya merupakan cara ilmiah untuk mendapatkan data dengan tujuan dan kegunaan tertentu (Sugiyono, 2015). Metode yang digunakan penulis adalah metode penelitian yang bersifat kualitatif dengan rancangan penelitian yang digunakan adalah studi kasus. Penelitian kualitatif ini memungkinkan untuk mendapatkan hal hal yang tersirat (insight) dan merupakan jenis penelitian formatif yang secara khusus memberikan teknik untuk memperoleh jawaban atau informasi mendalam tentang pendapat atau perasaan seseorang atas fenomena yang sedang terjadi (Sumantri, 2011).

Studi kasus adalah studi yang mengeksplorasi suatu masalah dengan batasan masalah yang terperinci, memiliki pengambilan data yang mendalam, dan menyeretkan berbagai macam informasi. Dalam penelitian ini data yang dikumpulkan dan dinyatakan dalam bentuk kata-kata, kata-kata disusun dalam kalimat, misalnya kalimat hasil wawancara antara peneliti dengan informan (Sukmadinata, 2006).

\section{Informan Penelitian}

Informan atau narasumber adalah orang yang diwawancarai. Dalam hal ini, narasumber atau informan berkedudukan sebagai penjawab pertanyaan atau pemberi informasi. Narasumber yang diwawancarai biasanya merupakan seseorang yang memiliki keterkaitan dengan perihal informasi yang diperlukan. Dalam hal ini, narasumber dapat berupa tokoh, ahli, atau orang biasa. Dalam penelitian ini yang menjadi subjek penelitian adalah petugas kesehatan atau petugas penerimaan pasien rawat jalan di Rumah Sakit X. Informan pada penelitian ini adalah

1. Petugas penerimaan pasien rawat jalan inisial " $A$ " selaku informan 1

2. Petugas penerimaan pasien rawat jalan inisial " $B$ " selaku informan 2

Informasi yang diperoleh mempunyai keterkaitan dengan manajemen pelayanan rawat jalan. Pemilihan sampel dilakukan sesuai dengan prinsip-prinsip yang berlaku dalam penelitian kualitatif yaitu:

a. Kesesuaian (appropriateness) yaitu sampel dipilih berdasarkan pengetahuan yang dimiliki berkaitan dengan topik penelitian.

b. Kecukupan (adequacy) yaitu data yang diperoleh dari sampel seharusnya dapat menggambarkan seluruh fenomena yang berkaitan dengan topik penelitian. 


\section{HASIL DAN PEMBAHASAN}

\section{A. Hasil Penelitian}

\section{Input}

\section{Sumber Daya Manusia}

SDM adalah semua orang/pegawai yang terlibat di dalam pelayanan pasien rawat jalan, di pendaftaran pasien Rumah Sakit X di setiap tahapan mulai dari tahap penerimaan, pelayanan rawat jalan dan administrasi.

Tabel 1. komposisi pegawai loket pendaftaran

\begin{tabular}{lclc}
\hline No & Jenis Kelamin & Masa Kerja & Pendidikan Terakhir \\
\hline 1 & Deriel & 4 Tahun & SMA \\
\hline 2 & Dewi & 17 Tahun & SMA \\
\hline 3 & Enur & 15 Tahun & SMA \\
\hline 4 & Fannisa & 2 Tahun & SMA \\
\hline 5 & Fikri & 4 Tahun & SMA \\
\hline 6 & Iing & 30 Tahun & SMA \\
\hline 7 & Iman B & 7 Tahun & SMA \\
\hline 8 & M. Yusuf & 3,5 Tahun & SMA \\
\hline 9 & Puji & 7 Tahun & SMA \\
\hline 10 & Yuni & 7 Tahun & SMA
\end{tabular}

Sumber: Rumah Sakit X

Berdasarkan tabel 1 di atas jumlah SDM di unit pendaftaran pelayanan rawat jalan seluruhnya berjumlah 15 orang. Loket pendaftaran dibuka mulai pukul 06.0020.00 WIB. Jam kerja SDM dibagi menjadi dua shift, yaitu shift pagi pukul 06.0013.00 WIB dan selanjutnya shift siang pukul 13.00-20.00 WIB. Upaya menangani pelayanan pendaftaran pasien akan terdapat permasalahan yang disebabkan adanya pasien yang kurang mengerti tata cara pendaftaran, sehingga akan memakan waktu dalam menjelaskan dan menyebabkan pegawai menjadi lambat dalam melayani pasien lainnya. Hal tersebut diungkapkan oleh informan " $A$ " sebagaimana dikutip pada wawancara berikut:

"iya, kadang ada pada saat baru mau memulai mengisi pendaftaran pasien,

kita mesti harus jelasin dulu untuk mengisi formulir pendaftaran agar tidak ada yang keliru”.

Sesuatu hal yang dihadapi semua pegawai selalu ada halangan atau kendala yang dialami, sebagaimana kendala yang dialami petugas pendaftaran pasien di Rumah Sakit X, kadang didapatkan pasien yang tidak membawa kartu data diri yaitu KTP jadi masalah bagi pegawai untuk memproses data pasien dengan lengkap. Lalu kadang ada pula pasien lama yang lupa membawa kartu berobat yang juga jadi masalah bagi pegawai untuk memproses penerimaan pasien rawat jalan, akan tetapi pasien mengetahui tanggal lahir ataupun alamat sesuai waktu berobat sebelumnya, petugas akan mudah untuk memproses data pasien. Hal tersebut sebagaimana diungkapkan oleh informan "B" dikutip dalam wawancara berikut:

"kendalanya ya gitu, kadang ada pasien yang tidak membawa KTP atau kartu berobat, asalkan pasiennya tahu tanggal lahir atau alamat dia sesuai waktu berobat sebelumnya, akan mudah". 
Menurut Handoko sumber daya yang penting dalam suatu organisasi adalah SDM, yang mana merupakan orang orang yang memberikan tenaga, bakat, kreativitas, dan usaha mereka kepada organisasi. Unsur manusia merupakan faktor

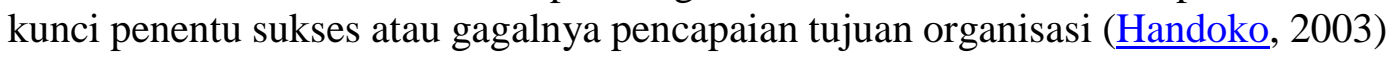

\section{Sarana}

Sarana adalah peralatan, ruangan dan fasilitas pendukung lainnya yang dipergunakan dalam pelaksanaan kegiatan penerimaan pasien rawat jalan. Kelengkapan sarana dan fasilitas pendukung dalam kegiatan kerja mendukung optimalisasi keberhasilan dari suatu aktifitas kerja. Pada ruang pelayanan pendaftaran pasien sarana yang ada sudah cukup memadai bagi pegawai yang ada di ruang pendaftaran pasien. Segala kegiatan yang dilakukan berhubungan dengan data pasien, dengan adanya sarana yang cukup memadai sangat mendukung bagi pegawai loket pendaftaran. Hal tersebut sebagaimana diungkapkan oleh informan "A" dikutip dalam wawancara berikut:

"iya sudah cukup memadai"

Berdasarkan observasi penulis, ruangan yang ada pada pelayanan pendaftaran pasien yang berada di lantai bawah dasar pintu masuk Rumah Sakit X, merupakan ruangan atau tempat pasien untuk pertama kali mendaftarkan identitas dan mengisi segala persyaratan yang berhubungan dengan pelayanan pendaftaran pasien rawat jalan, di ruang loket pendaftaran pasien terdapat 4 tempat untuk pelayanan pasien rawat jalan, semua pegawai akan berada di tempat tersebut agar memperlancar proses pelayanan dan tidak terjadi pengantrian lama. Terdapat komputer, printer, meja, kursi, lemari dan fasilitas sarana lainya yang mendukung pelayanan pendaftaran pasien.

Hal ini sudah sesuai dengan pendapat menurut (Jacobalis, 2005) yang menyatakan ketentuan mengenai sarana yang baik, penampilan fisik berpengaruh terhadap pelayanan pasien, petugas pelayanan perlu meningkatkan penataan dan kerapian ruang pelayanan dalam mengatasi persepsi buruk dalam pelayanan kesehatan.

\section{Proses}

\section{Pelayanan awal pasien}

Secara umum tidak ada pemisahan untuk penerimaan pasien dalam pelayanan pasien di Rumah Sakit X. Fungsi dan tugas pokok loket pendaftaran adalah sebagai unit sentral untuk pelayanan petugas kepada pengunjung, dimana loket pendaftaran merupakan awal mula pelayanan yang diberikan petugas pendaftaran. Semuanya disatukan untuk diarahkan ke poli masing-masing, sebelum memulai pendaftaran pasien, petugas pendaftaran pasien terlebih dahulu memastikan sekaligus menyiapkan formulir dan catatan rekam medis sudah siap dan ada, meliputi: Formulir pendaftaran, KIB (Kartu Indeks Berobat), Dokumen Rekam Medis (DRM) rawat jalan lainnya, pulpen, spidol, lem, gunting dan alat tulis kantor lainnya guna menunjang proses pelayanan pendaftaran.

Apabila pasien pertama kali melaksanakan pendaftaran di rumah sakit, pasien harus mengisi formulir pendaftaran yang telah disediakan di loket pendaftaran guna untuk melengkapi penginputan data pasien. Pasien juga harus memberikan identitas diri apakah pasien sudah pernah berobat ke rumah sakit tersebut atau belum pernah. Petugas akan menanyakan kartu berobat pasien untuk 
ditunjukkan ke petugas pendaftaran guna memudahkan administrasi pasien di bagian rekam medis. Setelah menyelesaikan pendaftaran pasien, petugas arsip rekam medis akan mengantarkan data pasien ke poli yang dituju untuk mendapatkan pelayanan perawatan medis.

Setiap pasien yang sudah mendaftar akan diarahkan ke kasir untuk pembayaran administrasi pelayanan pendaftaran pasien. Hal ini sejalan dengan teori tentang kualitas Pelayanan menurut (Tjiptono, 2005) mencakup pengertian: kesesuaian dengan persyaratan, kecocokan untuk pemakaian, perbaikan berkelanjutan, bebas dari kerusakan/cacat, pemenuhan kebutuhan pelanggan sejak awal dan setiap saat, melakukan segala sesuatu secara benar dan sesuatu yang bisa membahagiakan pelanggan.

\section{Pendaftaran pasien}

Pendaftaran Pasien adalah pelayanan yang diberikan kepada pasien yang masuk rumah sakit untuk mendapatkan pelayanan medis untuk tujuan pengamatan, diagnosis, pengobatan, rehabilitasi dan pelayanan lainnya. Pasien akan didaftar secara detail oleh petugas dengan pengisian data yang lengkap oleh pasien (Rahman, 2017). Setiap pasien pertama kali datang harus mendaftar di bagian pendaftaran untuk pengurusan administrasi pendaftaran dan pasien harus menunjukkan kartu identitas pasien.

Semua data pasien akan dicatat oleh petugas pendaftaran. Mencatat identitas ke formulir rekam medis rawat jalan. Data pasien tersebut akan di input kedalam komputer. Hambatan yang kadang terjadi ialah ketika akses internet error sehingga petugas menjadi mengulang mendaftarkan pasien kembali sehingga pasien menunggu lebih lama. Sebagaimana diungkapkan oleh informan "A" dikutip dalam wawancara berikut:

"paling kalau misalnya tiba tiba loading, error, nanti kita input ulang"

Setiap pasien yang sudah mendaftar di bagian pendaftaran pasien akan diberikan nomor antrian guna menunggu dipanggil untuk mendapatkan pelayanan medis dari poli yang akan dituju, Hal tersebut dikutip dalam wawancara oleh informan "B" dikutip dalam wawancara berikut:

"Kasih nomor antrian, kita arahkan untuk pembayaran ke kassa lalu menunggu di poli, lalu nanti oleh petugas medis akan dipanggil kembali untuk mendapatkan pelayanan medis".

\section{Administrasi}

Administrasi adalah proses administrasi dalam pengurusan kelengkapan persyaratan pendaftaran pasien dimulai dari pasien masuk sampai pasien pulang (Fether \& Barsasella, 2015). Administrasi rumah sakit adalah 'pintu gerbang' untuk melakukan pendaftaran dan pengurusan kartu untuk rawat jalan maupun rawat inap. Seorang bagian administrasi akan bekerja melayani pasien yang datang ke loket administrasi sesuai sub bagian atau divisi rumah sakit. Selanjutnya, bagian administrasi akan menjembatani komunikasi serta kebutuhan pasien terhadap dokter, perawat dan tenaga medis lainnya.

\section{Pendaftaran Pasien}

Dalam pengadminitrasian pendaftaran pasien maka petugas mencatat, membukukan dan menyimpan semua data pasien di dalam komputer dan disimpan 
di ruang rekam medik. Data pasien yang tersimpan akan digunakan oleh pasien bila berkunjung ke rumah sakit lagi untuk mendapatkan pelayanan medis berikutnya. Sesuai dengan kutipan wawancara sebagai berikut:

"iya itu memang tugas kita untuk melakukan pencatatan dan penyimpanan data pasien di dalam komputer dan disimpan di ruang rekam medik akan digunakan suatu saat oleh pasien bila berkunjung ke Rumah Sakit lagi untuk mendapatkan pelayanan kesehatan".

\section{Pelayanan pasien}

Petugas dalam pengurusan pelayanan data pasien yang dimaksudkan adalah dimana data pasien (status pasien) yang telah tersimpan di rekam medis akan dibawa oleh petugas arsip ke poli yang akan dituju pada saat pasien berkunjung di rumah sakit guna mendapatkan pelayanan medis, data status pasien sesudah selesai diproses di poli yang dituju maka petugas akan mengambil data tersebut untuk disimpan kembali di ruang rekam medik. Hal tersebut sesuai dengan kutipan wawancara sebagai berikut:

"Iya, petugas lah yang bertugas mengantar data pasien yang telah disimpan direkam medik ke poli yang dituju, data akan diambil lagi oleh petugas setelah selesai pelayanan di poli."

\section{Output}

Dari input dan proses yang telah terpapar di atas, maka dalam komponen output untuk melihat hasil keluaran atau proses pelayanan pendaftaran pasien. Proses output untuk mengetahui data pasien yang telah terdaftar di bagian pendaftaran pasien akan diproses. Semua data pasien yang tersimpan di rekam medis akan dibawa oleh petugas loket pendaftaran untuk diantarkan di bagian poli masing-masing. Setelah mendapatkan pelayanan medis maka pasien pulang.

\section{B. Pembahasan}

Salah satu kegiatan rekam medis di Rumah Sakit X yang pertama adalah penerimaan pasien di rawat jalan atau rawat inap. Dalam menangani pelayanan pendaftaran pasien akan terdapat permasalahan yang disebabkan adanya pasien yang kurang mengerti tata cara pendaftaran, sehingga akan memakan waktu dalam menjelaskan dan menyebabkan pegawai menjadi lambat dalam melayani pasien lainnya.

Penerimaan pasien rawat jalan di Rumah Sakit X cukup baik dan sesuai dengan Direktorat Jenderal Bina Pelayanan Medik tentang sistem informasi manajemen Rumah Sakit yang terintegrasi komputerisasi. Namun ada sedikit keterlambatan saat penerimaan pasien diantaranya saat pasien kurang membawa persyaratan untuk berobat dan masih ada terjadinya error pada sistem informasi di bagian pendaftaran.

Dilihat pada hasil diatas bahwa pengaruh prosedur penerimaan pasien rawat jalan mempunyai pengaruh yang kuat terhadap efektivitas pelayanan. Untuk itu penulis melakukan penelitian ini bertujuan untuk mengetahui prosedur penerimaan Pasien Rawat Jalan guna Menunjang Efektivitas Pelayanan Rekam Medis di Rumah Sakit X.

\section{KESIMPULAN}

Setelah penulis sudah melaksanakan praktek kerja lapangan di Rumah Sakit X dari pembahasan sebelumnya, maka dapat diambil kesimpulan yaitu prosedur penerimaan 
pasien rawat jalan di Rumah Sakit X sudah baik namun belum cukup efektif dikarenakan adanya ketidaklengkapan informasi data dari pihak pengantar pasien atau keluarga pasien kepada petugas untuk di input datanya, mengakibatkan ada nya jeda atau waktu tunggu pendaftaran pasien lain sehingga mempengaruhi waktu pelayanan.Permasalahan yang timbul dari prosedur penerimaan pasien rawat jalan di Rumah Sakit X diantaranya kekeliruan petugas karena sistem informasi di pendaftaran pada saat akan mendaftarkan pasien error sehingga petugas menjadi mengulang mendaftarkan pasien kembali sehingga pasien menunggu lebih lama. Upaya pemecahan masalah yang telah dilakukan oleh pihak Rumah Sakit X petugas pendaftaran mensosialisasikan kelengkapan data pasien seperti KTP atau kartu pengenal lainnya kepada pasien atau pihak pengantar pasien serta mensosialisasikan bahwa kelengkapan identitas atau informasi identitas pasien sangat penting dalam proses pendaftaran, dan petugas pendaftaran berupaya untuk menginput data pasien kembali dengan cepat pada saat jaringan koneksi internet sudah membaik.

\section{BIBLIOGRAFI}

Fether, B., \& Barsasella, D. (2015). Analisis Sistem Pendaftara N Pasien Rawat Jalan Di Puskesmas Kecamatan Duren Sawit Jakarta Timur 2014. Jurnal Manajemen Informasi Kesehatan Indonesia (JMIKI), 3(1).

Handoko, T. H. (2003). Manajemen Personalia dan Sumber Daya manusia, edisi keempat. Yogyakarta, Penerbit: BPFE.

Indonesia, R. (44 C.E.). Undang-Undang Republik Indonesia Nomor 44 Tahun 2009 Tentang Rumah Sakit.

Jacobalis, S. (2005). Pengantar tentang perkembangan ilmu kedokteran, etika medis dan bioetika. Sagung Seto Bekerjasama Dengan Universitas Tarumanegara, Jakarta.

Permenkes, R. I. (2008). No 269/Menkes/Per/III/2008 tentang Rekam Medis. Jakarta: Menteri Kesehatan Reupublik Indonesia.

Rahman, M. (2017). Kualitas Layanan Kesehatan Pasien Peserta Badan Penyelenggara Jaminan Sosial (BPJS) di Rumah Sakit Universitas Hasanuddin. Jurnal Ilmiah Ilmu Administrasi Publik, 7(1), 30-37.

Sedarmayanti. (2009). Sumber Daya Manusia Dan Produktivitas Kerja. Bandung: CV Mandar Maju.

Sitanggang, T. (2019). Aspek Hukum Kepemilikan Rekam Medis Terhadap Perlindungan Hak Pasien. Yayasan Kita Menulis.

Sugiyono. (2015). Metode Penelitian Manajemen. Bandung: Alfabeta.

Sukmadinata. (2006). Metode Penelitian Kualitatif. Bandung: Graha Aksara.

Sumantri, A. (2011). Metode Penelitian Kesehatan (Pertama). Jakarta : Kencana.

Supartiningsih, S. (2017). Kualitas pelayanan kepuasan pasien rumah sakit: kasus pada pasien rawat jalan. Jurnal Medicoeticolegal Dan Manajemen Rumah Sakit, 6(1), 915.

Tjiptono, F. (2005). Strategi Pemasaran I (Kedua). Yogyakarta : Andi Offset.

(C) 2021 by the authors. Submitted for possible open access publication under the

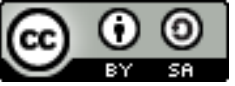
terms and conditions of the Creative Commons Attribution (CC BY SA) license (https://creativecommons.org/licenses/by-sa/4.0/). 